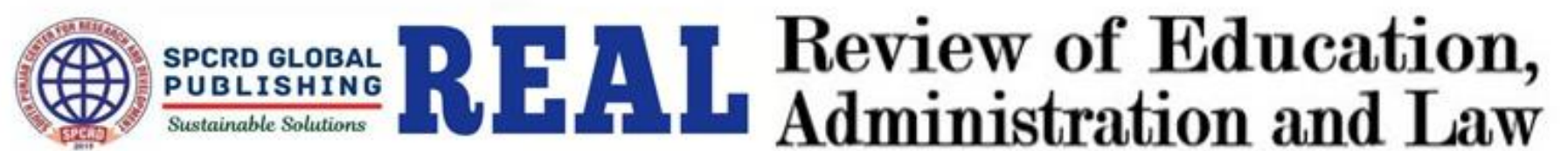 \\ Journal homepage: http://real.spcrd.org ISSN (Print): 2708-1788ＩSSN(Online): 2708-3667
}

\section{Need of Legal, Administrative and Judicial Reforms in Pakistan to Combat Money Laundering and Terrorism Financing: An Analytical Study}

\author{
Khalil Haider a, Naureen Akhtar ${ }^{\text {b }}$ \\ a LLM Scholar, University Gillani Law College, Bahauddin Zakariya University, Multan, Pakistan \\ ${ }^{\mathrm{b}}$ Assistant Professor of Law, University Gillani Law College, Bahauddin Zakariya University, Multan, Pakistan
}

\begin{tabular}{|c|c|}
\hline ARTICLE DETAILS & ABSTRACT \\
\hline Hist & \multirow{12}{*}{$\begin{array}{l}\text { The main objective of this article is to discuss, review and analyze } \\
\text { money laundering and terrorism financing simultaneously as both share } \\
\text { common incentives, line of action and executing strategies. Money } \\
\text { laundering and financing of terrorism are global problems which not } \\
\text { only threaten security but also compromise the stability, transparency } \\
\text { and efficiency of financial systems, thus undermining economic } \\
\text { prosperity and peace of a country. This research defines and expounds } \\
\text { the terms 'money laundering' and 'terrorism financing', and common } \\
\text { strategies to execute both of these criminal activities. It also analyzes the } \\
\text { current predicament of legal, administrative and judicial skeleton of } \\
\text { Pakistan which makes the country more vulnerable to money laundering } \\
\text { and terrorism financing. Furthermore, it would also provide its readers } \\
\text { with the most needed reforms in the all-over blueprint of the country, } \\
\text { and imperative amendments to make the Anti-money Laundering Act, } \\
\text { 2010 and the Anti-terrorism Act, 1997 more efficacious to encounter } \\
\text { money laundering and terrorism financing in one fell swoop. }\end{array}$} \\
\hline ted 22 May 2020 & \\
\hline Available Online 30 June 2020 & \\
\hline Keywc & \\
\hline Money Laundering; Terrorism & \\
\hline Fina & \\
\hline Judic & \\
\hline Act, 2010 & \\
\hline Act, & \\
\hline JEL Classi & \\
\hline & \\
\hline DOI: $10.47067 /$ real.v3i & \\
\hline
\end{tabular}

(C) 2020 The authors. Published by SPCRD Global Publishing. This is an open access article under the Creative Commons Attribution-

NonCommercial 4.0

Corresponding author's email address: naureen.akhtar@bzu.edu.pk

\section{Introduction}

Money has become a concept, an idea and a belief nowadays. The one and only unavoidable fact of money is that everyone, around the globe, is struggling, planning, fighting, lusting and plotting for it (John Madinger, 2012). This lust for money gave birth to various novel crimes in the world. Crimes particularly revolving around the money include tax evasion, forgery, credit card fraud, money laundering, terrorism financing, mortgage fraud, embezzlement, insider trading, currency crimes, bank fraud, identity theft, etc. (Department of Justice \& Equality, 2019).

Among these financial crimes, money laundering and terrorism financing have become panic for the whole world. According to estimation of United Nations' officials, the annual money laundering and 
terrorism financing figure is more than two trillion US dollars worldwide (United Nations Office on Drugs and Crime, n.d). One major cause of this terrible spike in these figures is use of online mediums for financial transactions. The rapid progress in the field of information technology, the number of transactions through online channels has been also increased. Criminals have taken advantage of this increase in number of online transactions for money laundering as well as terrorism financing (Emerald Group of Publication, 2014). Undoubtedly, Money laundering and terrorism financing are two different types of crimes with their own purposes. Former is primarily concerned with the concealment of source of money to make illegitimate money appear legitimate. While in the latter's case, destination of money is to be concealed as the final objective of funds is unlawful. However, in both cases, criminals go through a similar strategy and to use common means to have their own ends.

At international level, therefore, battle against money laundering and terrorism financing is being fought simultaneously. This trend can be observed in the work style of the Financial Action Task Force (FATF), World Bank, International Association of Insurance Supervisors (IAIS), International Organization of Securities Commissions (IOSCO), International Criminal Police Organization (INTERPOL), and in international instruments like United Nations Security Council Resolution 1373 of 2001, the FATF Recommendations 2012, and the Directive (EU) 2015/849 of the European Parliament and of the Council.

In Pakistan, soaring numbers of organized financial crimes and terrorist activities have set alarm bells ringing on the fate of the state. According to an International Narcotics Control Strategy Report by United States' State Department, more than ten billion US dollars are laundered annually in Pakistan (Anwar Iqbal, 2020). In 2018, Financial Action Task Force (FATF) showed grave concerns on then prevalent condition of money laundering and terrorism financing, and placed Pakistan in its 'Grey List' (Anwar Iqbal, 2018). Undoubtedly, Pakistan has made, since then, a sincere pledge to FATF and international community to take severe actions against money launderers and terrorism financers operating within the country. In the recent FATF's February 2020 meeting, Pakistan succeeded to convince the international watchdog in apropos of compliance to at least 14 points out of 27. However, FATF kept Pakistan in its grey-list till its next meeting to be held in June 2020. So, Pakistan will have to be strictly compliant on remaining 13 points to get out of the grey list (Mehtab Haider, 2020).

Development of a country is primarily based on wellness of its economic and social life. Money laundering and terrorism financing may be proved to be poisonous for economic and social growth of a country. This article shows how money laundering and terrorism financing are eroding Pakistan's economy and peace to the core. The article suggests the most needed amendments in the Anti-money Laundering Act, 2010 and the Anti-terrorism Act, 1997. Furthermore, it would, on one hand, endeavor to highlight flaws in the all-over infrastructure of the country and on the other hand, it also offers recommendations to remove those flaws to have an economically and socially stable homeland.

\section{Understanding the Concepts and Common Methods of Money Laundering and Terrorism Financing}

Criminals involved in financial crimes desire not only to evade penal action but also the criminal proceeds. Enjoying the fruits of illegal money by covering-up the actual source of money is a very old practice. However, the term 'money laundering' evolved in the second and third decade of the last century when a US gang earned a lot of money through criminal activities like theft, robbery, extortion, prostitution and kidnapping. The gangsters involved themselves in a Laundromat business to mix up money acquired from their illegal activities and that procured from lawful business, and hence, the term 'money laundering' evolved (C.J. Oakes, 2018). 
A brief but comprehensive exposition of the term is, "a multi-layered process of using money, derived through illegal means, by concealing its source or the identity of person(s) who obtained the money, and then disguising that money to make it appear as legitimate.” (James Chen, 2019)

Three basic phases are involved to launder 'dirty' money to make it appear 'clean'. These three phases are:
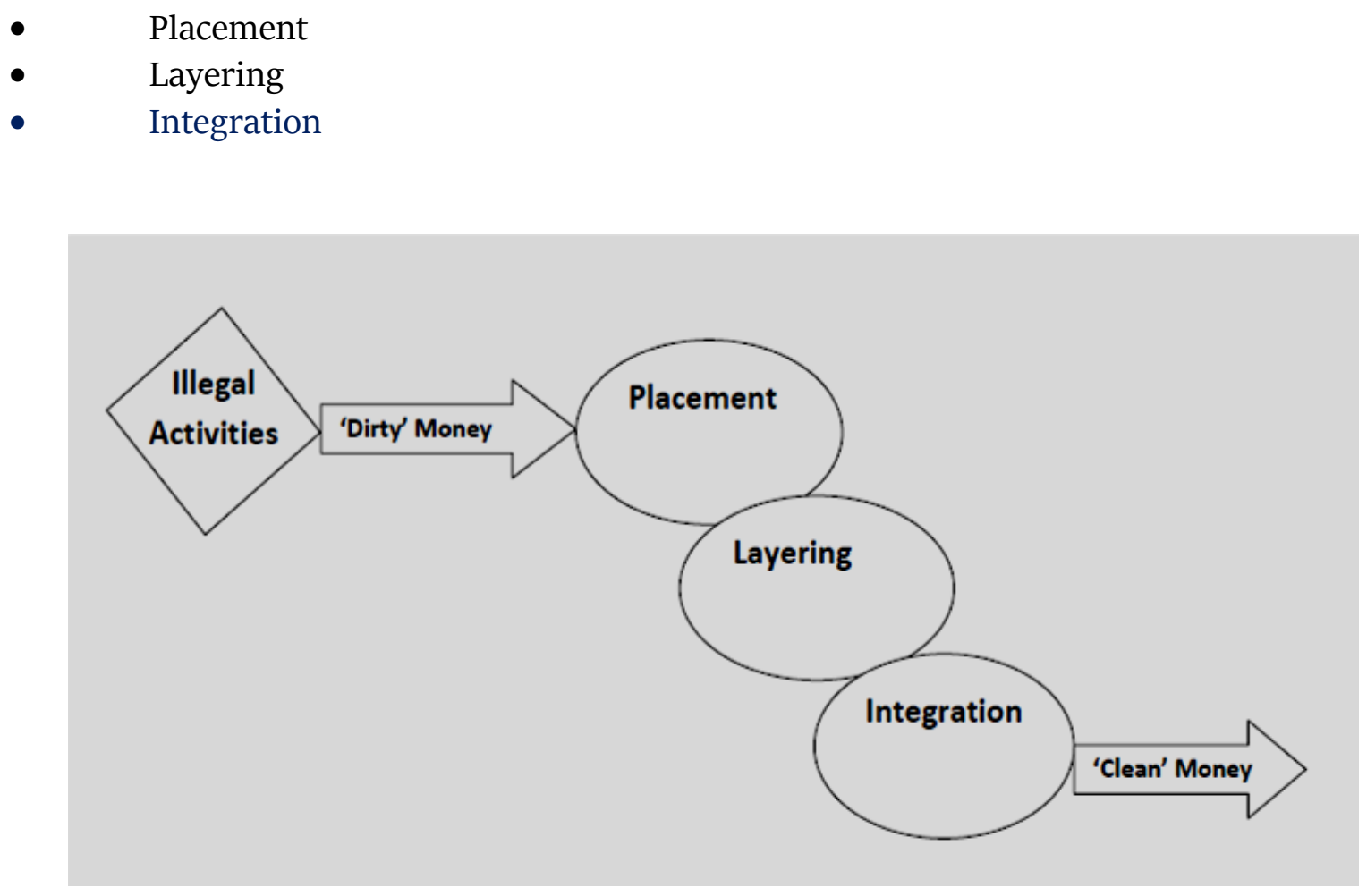

In the first phase of money laundering i.e. placement, money procured from criminal activities is placed in a financial system. Illegal money can be introduced in financial system through depositing the same in national or foreign banks, casinos or other financial and non-financial departments. At this stage of placement, technique of 'structuring' or 'surfing' is commonly practiced by money launderers. Bulk of illegal money is broken and introduced in a financial system in different installments and in such a pattern to avoid from detecting as unusual transaction by law enforcement departments and agencies (https://people.exeter.ac.uk/watupman/undergrad/ron/methods\%20and\%20stages.htm.).

After introducing illegal money in a financial system, the next stage is 'layering'. During this stage, illegal money is substantially distanced from its actual source. For this purpose, illicit money is folded up in a number of layers of transactions. The transactions during this stage may be of different types, for instance, transfer of funds in different national and international bank accounts for multiple times, investment in different legal businesses, and sale and purchase of highly valuable items (Brett A. Podolsky, 2018). Through these multiple transactions, that first transaction at the stage of placement is to be made beclouded. Consequently, real source, real owner and trail of that illicit money are compressed and become obscure beneath the layers of manifold transactions.

After the first two stages, that 'dirty' money has been 'cleansed' and is almost ready to get its new legal costume. So, now it is the time to reintroduce the illicit money in a financial system as legitimate money. This stage is called 'integration'. Money launderers have multiple options for this stage of integration. For instance, he may choose to invest in real estate sector; purchase highly valuable ornaments or automobiles (J. C. Sharman, 2011). 
All the stages involved in money laundering are the combination of multiple and complex transactions and are not easily separable. If illegal money succeeds to go through all these three stages, it gets a virtual stamp of legitimacy and it becomes almost impossible for law enforcement departments to get triggered (Daniel Clark, 2020). Therefore, it is a requisite for a watertight law enforcement system encountering money laundering is to detect illicit money while the same is in a stage of money laundering.

On the other hand, financing of terrorism has become another threat for the peace of world since the beginning of this century (Stefan D Cassella, 2019). Like any other organization, a terrorist organization also depends on money to run its internal affairs and execute criminal activities. A terrorist organization needs another organization folded up in a legally acceptable costume to spread the former's ideology. That front organization commonly runs different social and educational projects in a targeted society (Aimen Dean, Edwina Thompson and Tom Keatinge, 2019). It also has to have some favorable personnel of government offices in its support.

A terrorist organization, unlike a legal organization, cannot publish an advert in a newspaper for recruitment. It has to spend a lot of time and money to have fresh inductees and to train them (Financial Action Task Force, 2018). It has to pay its active terrorist members to make them able to financially support their families. Before an actual terrorist activity, a terrorist organization has also to see how the land lies, and for execution of a terrorist activity, terrorists have to move from their place to targeted place, stay there, execute the activity and safely return back to their place (Eben Kaplan, 2006).

A terrorist organization also supports heirs of assassinated terrorists to encourage them to join the organization. Thus, for all these affairs, such an organization always remains in dire need of money, and obviously, it has no concern whether that money is legitimate or otherwise. Therefore, for collection of money, terrorists also get themselves involved in some other criminal activities like theft, robbery, extortion, kidnapping for ransom etc. A terrorist organization also raises funds from targeted society through its front organizations. As a result, round the globe, terrorism financing is considered tantamount to terrorism itself and being handled with iron hands to curtail terrorism since the 9/11 attacks of 2001 (Rand Corporation, 2019).

Therefore, unlike money laundering, in case of terrorism financing final disposal and objective of money is to be concealed and avoided from being detected. However, as the front organization or , as the case may be, an individual sponsor conceals final destination of its money, likewise, terrorist organization also procures and utilizes the funds without leaving any trail that may lead law enforcement departments to the organization itself, its front organization or other financers. That is why the source of funds of a terrorist organization is also pertinent for law enforcement agencies to explore the whole network of the organization.

Money laundering and terrorism financing, as previously described, are distinct types of crimes and have different purposes. It is the source of money that is to be concealed in money laundering, while in the latter's case, so is the last terminus of money fundamentally. However, mysterious ties often unite both types of crimes in mysterious ways. By keeping a close eye on different terrorist organization, one can easily comprehend the fact that majority of terrorist organizations are operating from places rich in natural resources and raw materials. The Islamic State of Iraq and Syria (ISIS) operated from Mosul and other northern and eastern sides of Iraq. The areas are rich in mineral oil and income of ISIS was more than one million US dollars per day (Rachel Kreisman, 2017). Revolutionary 
Armed Force of Colombia (FARC) operated, during its operational years, from the areas of Colombia rich in coca crops. According to an estimate, FARC had control over 70 percent of total coca crops of Colombia and had been earning 60-100 million US dollars annually (Jean-François Thony, 200o). In Afghanistan, Taliban captured areas Helmand, Kandahar, and Nimruz are arable lands for growth and cultivation of opium plants. Taliban is earning more than four hundred US dollars annually (Gretchen Peters, 2009). All these raw materials are useless for a terrorist organization until they are sold and turned into money.

Apart from bulky earnings of terrorist organizations, a real question is who buys these commodities from them? The answer to the question reveals the nexus between terrorist organizations, their financers, money launderers and other organized criminals. A terrorist organization needs a buyer of these commodities and raw materials. None but money launderers and other organized criminals buy the same at very low prices (Jean-François Thony, 2000). Money launderers run this business under the cover of their other legitimate businesses to make their all earnings appear legitimate. So, in this way, the criminals rotate currency between each other, and consequently, criminals engaged in cleansing of illegitimate income may play the role of primary or ancillary financers of terrorist organizations.

Apart from this nexus of money laundering, terrorism and terrorism financing, there are a number of similar channels, methods and strategies which are commonly put to use by the criminals hiding the origin of income as well as terrorism-financers to carry out their respective offences. Money launderers usually open fake bank accounts; abuse banking and other financial institution facilities; incorporate front companies; create trusts; use informal banking process hawala/hundi; involve credit cards; and smuggle cash to whiten their black money. All these methods are being employed by financers and facilitators of terrorist organizations (Clare Chambers-Jones, 2012).

Furthermore, with the rapid increase in use of information technology in each sector, money launderers have been also using virtual currency, online games and online gambling applications as efficient and quick tools to launder money. By the same token, terrorist front organizations and individual sponsors are also using the same online channels to transfer funds to terrorist organizations. At this moment in time, a financer of terrorist organization can go to casino or use online gambling applications to play with a member of the organization. The former can intentionally lose in favor of the latter to transfer funds (Financial Action Task Force, 2009). Moreover, terrorists and their front organizations are also using online channels to spread propaganda, to recruit new members, to provide social services to get sympathy, and to raise funds from public.

\section{Key Problems in AML/CFT Framework of Pakistan and Their Solutions}

Pakistan has been placed on grey list of FATF for three times. For the first time, Pakistan was placed in the list in 2008 for having a very poor infrastructure against both types of criminals. Pakistan was placed in the list again in 2012. In 2015, Pakistan succeeded to get confidence of international community regarding its measures against money laundering and terrorism and got out of the list. In 2018, Pakistan once again lost confidence of the international watchdog and was placed in the list (Shahid Karim and Usama Hayat, 2019). The eighth edition of Basel AML Index 2019 has ranked Pakistan 23 out of 125 countries with the highest money laundering and terrorism financing risks (Basel Institute on Governance, 2014). So, keeping in view the guidelines of international organizations, infrastructure of Pakistan encountering money laundering and terrorism can be segregated into legislative, administrative and judicial facets to precisely pinpoint problems of and provide solutions for each pillar of the state. 


\subsection{Legislative Reforms}

The basic enactments in apropos of money laundering and terrorism, in Pakistan, are the Antimoney Laundering Act, 2010 (hereinafter referred to as AMLA, 2010) and the Anti-terrorism Act, 1997 (hereinafter referred to as ATA, 1997) respectively.

The AMLA, 2010 succeeded and repealed the Anti-money Laundering Ordinance, 2007 and provides a number of new and refined provisions (Banker's Academy, 2019). However, it didn't meet expectations to provide an exhaustive and watertight framework. For instance, its section 4 provides the punishment not less than 1 year and not more than ten years rigorous imprisonment, and fine up to 1 million rupees along with confiscation of property involved in the commission of the offence falling under section 3. Keeping in mind the whole scheme of criminal administration of justice of Pakistan, punishment provided for such a heinous crime is an inadequate sentence and it must not be less than three years and may extend to life imprisonment.

The AMLA, 2010 doesn't provide a separate judicial structure to try and adjudicate the accused. Rather, s. 20 of the Act makes the offence of triable by an ordinary Session courts. The matter will be discussed in detail hereinafter. Likewise, offences under AMLA, 2010 has been declared as noncognizable under s. 16 and 20. The powers of investigation officer to survey a place suspected to be involved in commission of an offence under the Act, to search any building, examine any person, and to seize any record or property are exercisable with the preceding approval of the court (s. $13 \& 14$ ). In case of violation, investigation officer has been made liable to punishment under the section 32 of the Act.

On the other hand, the ATA, 1997, as firstly enacted, primarily focused the subject of terrorism and not financing thereof. The Act was substantially amended in 2013 through Anti-terrorism (Second Amendment) Act 2013 (XX of 2013) (Tariq Ahmad, 2013). The amending Act incorporated different provisions, inter alia, against funding and facilitation of terrorist organizations. The amendment Act XX of 2013 included financer and facilitator of terrorism acts in the definition of 'terrorist'. The amending acts also introduced clause (1A) to Section 11E of the ATA, 1997 whereby concerned state institutions are prohibited from issuing passports and allowing to go abroad, and banks and other financial institutions are debarred from having any kind of pecuniary relations with such an association, its members, activists and any kind of their associate who remain involved in criminal activities after proscription.

Lawmakers, in Pakistan, never attempted to correlate money laundering and terrorism financing. Preamble of the AMLA, 2010 provides combating financing of terrorism along with money laundering as the main theme of the Act. However, adequate provisions are not provided by the Act to make a holistic approach against the former along with the latter offence. Nor the Act includes any office bearer of provincial counter-terrorism departments as a member of National Executive Committee (NEC) or General Committee formed by its s. 5. Same is the case with the ATA, 1997 that also doesn't provide for law enforcement institutions to probe a case of financing of terrorism keeping in mind its probable link-ups with money launderers (Imran Ali, 2019). Although its s. 11K provides punishment for facilitation of retention or control of property involved in or obtained from terrorism, and name the offence as 'money laundering'. Therefore, money laundering defined and penalized by the ATA, 1997 only relates to control and retention of terrorist property and it has nothing to do with money laundering of other criminal proceeds. So, for a watertight anti-money laundering and antiterrorism financing legal regime, plenty of statutory provisions must be provided by legislature for administration for each case of terrorism financing to find out it's probable link-ups with money launderers and vice versa. 


\subsection{Administrative Reforms}

Pakistan is considered to be very quick at enacting laws but very sluggish when it comes to putting laws into action (Pakistan Today, 2019). A Financial Monitoring Unit (FMU) was formulated by the Section 6 of the AMLA, 2010. FMU was obliged, inter alia, to collect record of Suspicious Transactions Reports STRs, Currency Transaction Reports CTRs and other information, and to disseminate the concerning information to all other concerned investigating agencies. However, in practice, data of FMU and other financial intelligence is neither accessible to all counter terrorism agencies nor it is being used as a tool of investigation and inquiry of terrorism financing cases. Financial intelligence is being used in money laundering cases only (The Asia/Pacific Group Mutual Evaluation report, 2019).

Federal Investigation Agency (FIA) established Terrorist Financing Investigation Unit (TFIU) to probe the cases of terrorism financing with the help of data provided by FMU. However, only a few enquiries of financing of terrorism cases have been conducted so far on the request of FMU and other agencies (Federal Investigation Agency, 2019). Surprisingly, provincial Counter Terrorism Departments (CTDs) have no access to data of FMU. A provincial CTD can only have access to such information or data on prior permission of court of law. So, it is need of hour that all provincial CTDs must also have access to the data and results of FMU, and all such provincial and federal departments must utilize financial intelligence to probe terrorism financing cases (The Asia/Pacific Group Mutual Evaluation Report, 2019).

Furthermore, banks, Development Finance Institutions (DFIs), Micro Finance Banks (MFBs), and modarbas, insurance and other corporations, in Pakistan, have better comprehension of their duties in apropos of growing threats of money laundering. However, they are less familiar with the risks of terrorism financing through financial sector. Some old-fashioned departments like saving centers and Pakistan Post have neither understanding of money laundering and terrorism financing threats through their departments nor they know their obligations to minimize the risks (The Asia/Pacific Group Mutual Evaluation Report, 2019). Therefore, state institutions must oblige such departments to equip their staff with sufficient knowledge and training to observe a suspicious activity/transaction and trigger concerned authorities.

Another loophole in the financial sector of Pakistan is informal banking channel i.e. hawala/hundi. Billions of rupees are transferred annually to and from Pakistan through these channels (Muhammad Subtain Raza, Muhammad Fayyaz and Haseeb Ijaz, 2019). After 2018 general elections in Pakistan, a vigorous series of steps were taken by newly elected government against these operators (Aamir Latif, 2018). From only two hawala centers in Karachi, more than 400 million rupees were seized by FIA in a crackdown (The Frontier Post, 2019). Funds can be transferred through hawala/hundi without following the SOPs of the government institutions; hence this channel is routinely used by both kinds of criminals. Therefore, it is the duty of government to take follow-up of its actions of preceding years and handle operators of hawala/hundi with iron hands to crush the network of money launderers and terrorism financers in one go.

In Pakistan, currency smuggling is another favorable option for money launderers as well as terrorism financers as Pakistan shares a very long Durand Line (common name of border of Pakistan and Afghanistan) of approximately 2.5 hundred kilometers with Afghanistan. Pashtoons of both sides share common culture and language, so, they regard the border as soft one. Many of them have trained themselves to cross the border without being detected by the forces. Pakistan faces similar risks on PakIran border as well (Eltaf Najafizada, 2018). Cash smuggling by airplane (passenger or cargo) has been 
also commonly used by both money launderers and terrorism financers. Airline personnel have been often reported to be involved in cash smuggling (Jawed Asghar, 2017). So, through proper border control on Pak-Iran and Pak-Afghan border and construction of barriers on the latter; and by coordinated intelligence efforts on airports can help in minimizing the threats of both money laundering and terrorism financing.

\subsection{Judicial Reforms}

Judicial framework of Pakistan, specifically against money laundering and terrorism financing, has proved itself flawed and incompetent (Naeem Sahoutara, 2018). Unlike the ATA, 1997, the AMLA doesn't provide a separate and special judicial infrastructure to try and adjudicate the cases of money laundering. Rather, ordinary Session courts established under Code of Criminal Procedure (CrPC), 1898 has been empowered to try and adjudicate the cases. In like manner, no special procedure has been prescribed for trial of cases of money laundering, and provisions of $\mathrm{CrPC}$ have been made applicable to all trial and pre-trial stages of the cases.

The ATA, on the other hand, established special courts 'Anti-terrorism Courts' (ATCs) to try all scheduled offences under the Act. The Act also provided a plenty of procedural provisions for efficient and speedy trials, although some of them are unrealistic and infeasible. For instance, clauses 7 and 8 of its s. 19 adjure ATCs to complete each cause in seven working days and with no more than two adjournments. Same number of days is provided by s. 25 to a high court to dispose of an appeal while performing as an appellate forum. As of 2016, there are only 54 ATCs in the whole country while the total districts in Pakistan are 154 (Syed Manzar Abbas Zaidi, 2016). So, there is, on average, only one ATC for as good as three districts of the country. Hence, this insufficiency of available courts and factual condition of judicial structure make the provisions impracticable.

Moreover, an advocate of high court with seven year legal standing in a high court has been declared eligible, under section 22 of the AMLA, to be appointed as a public prosecutor. Like provisions regarding appointment of public prosecutors in ATCs can be found in section 18 of the ATA. Neither the AMLA nor the ATA advises special knowledge or educational qualification on the topic for eligibility to be a public prosecutor in either type of cases.

Section 25 of the ATA directs each high court to formulate special bench, comprised of not less than two judges, for hearing of appeals against the decisions of ATCs. The bench has been directed to decide an appeal within seven working days and without intervention of two consecutive adjournments. On the other hand, section 23 of the AMLA provides high court as the competent forum to hear appeal against the judgment of a money laundering case. Neither provisions for constitution of special bench nor any provision for speedy disposal of appeal has been provided by the AMLA.

Criminals engaged in organized and financial crimes are using modern and online techniques to achieve their ends. A judge and a public prosecutor of ordinary courts of law have no sufficient knowledge and expertise on these multifaceted topics. Untrained investigation team and untutored judicial officers collectively lead the conviction rate of money laundering and terrorism financing cases to single digits. So, for all above-mentioned reasons, current judicial infrastructure trying such kind of criminals' cases direly needs to be replaced by a skilful and well-informed judicial setup.

\section{Conclusion}

This article concludes that money laundering and terrorism are the main obstacles in economic growth, peace and security of a country. Existence of money launderers in a society is the sign of 
existence of smugglers, human and drug traffickers and other organized criminals for washing out criminal proceeds. On the other hand, financers of terrorism are the lifeblood of terrorist organizations. Apart from the common methods practiced by these criminals, they also imitate each other to effectuate their ends. Front organizations of terrorists also have to use different methods of money laundering to mix-up their legitimate and illegitimate funds to make their whole money appear legitimate. Likewise, some money launderers also play an indirect or direct role of financers of terrorist organizations.

Pakistan has been facing very high risks of money laundering and terrorism financing. Pakistan has taken a number of measures to satisfy the demands of FATF and other international organizations. However, all state institutions don't have a holistic approach against both money laundering and terrorism financing. Although Pakistan, complying with the demands of international organizations, enacted the AMLA, 2010 and the ATA, 1997, they call for serious consideration and amendments, especially the former, to provide a strict legal arena. All administrative institutions of the country must join hands and show a collective impact approach against the criminals. By the same token, judicial infrastructure of the state trying these cases should be replaced altogether or the current setup must be equipped with adequate comprehension and proficiency on the subject. This is the one and only way for Pakistan to get rid of the pollutants of money laundering and terrorism financing, and to be an economically prospering and socially peaceful and secure homeland.

\section{References}

Ahmad, T. (April 16, 2013). Global Legal Monitor. Accessed on April 24, 2020. Retrieved from https://www.loc.gov/law/foreign-news/article/pakistan-amendments-to-anti-terrorism-laws/.

Ali, I. Anti-money Laundering Act 2010: A Critical Analysis. Lums Law Journal. 5, 1-19. Accessed on August 31, 2019. Retrieved from https://sahsol.lums.edu.pk/law-journal/anti-money-laundering-act2010-critical-analysis.

Basel Institute on Governance. (2019). A country ranking and review of money laundering and terrorist financing risks around the world. Switzerland.

C. Sharman, J. (2011). The Money Laundry: Regulating Criminal Finance in the Global Economy. Cornell University Press.

Chambers-Jones, C. (2012). Virtual Economies and Financial Crime: Money Laundering in Cyberspace. United States of America: Edward Elgar Publishing ltd.

Chen, J. (June 25, 2019). Money Laundering. Accessed on 15th September, 2019. Retrieved from https://www.investopedia.com/terms/m/moneylaundering.asp.

D Cassella, S. Reverse Money Laundering. (2003). Journal of Money Laundering Control. 7(1), 92-94. Accessed on October 3, 2019. Retrieved from https://works.bepress.com/stefan_cassella/2/.

Dean, A., Thompson, E., and Keatinge, T. (2013). Draining the Ocean to Catch one Type of Fish: Evaluating the Effectiveness of the Global Counter-Terrorism Financing Regime. Perspectives on Terrorism. 7(4), 62-78. Accessed on October 3, 2019. Retrieved from https://www.jstor.org/stable/26296984.

Department of Justice \& Equality. Money Laundering \& Terrorist Financing - Are you aware?. Accessed on January 06, 2019. Retrieved from http://www.antimoneylaundering.gov.ie/en/AMLCU/Pages/Money_Laundering_Terrorist_Financing_Are_y ou_aware.

Emerald Group Publishing Ltd. (2014). Criminals move with the times: Money launderers and terrorism financiers go online. Strategic Direction. 30(6) (2014), 8-10. Accessed on May 1, 2020. Retrieved from https://doi.org/10.1108/SD-03-2014-0039.

Federal Investigation Agency. Counter Terrorism Wing (CTW). Accessed on September 15, 2019. Retrieved from http://www.fia.gov.pk/en/ctw.php. 
Financial Action Task Force. Financing of Recruitment for Terrorist Purposes. Paris, 2018.

Financial Action Task Force. Financing of Recruitment for Terrorist Purposes. Paris, 2018.

Financial Action Task Force. The FATF Recommendations. Paris, France, 2012-19.

Financial Action Task Force. Vulnerabilities of Casinos and Gaming Sector. Paris, France, 2009.

Kaplan, E. (April 04, 2006). Tracking down Terrorist Financing. Accessed on September 15, 2019. Retrieved from https://www.cfr.org/backgrounder/tracking-down-terrorist-financing.

Karim, S. and Hayat, U. (June 10, 2019). Pakistan on FATF's grey list: what, why, and why now?. Dawn. Accessed on October 5, 2019. Retrieved from https://www.dawn.com/news/1418143.

Kreisman, R. (May 15, 2017). Raqqa and the Oil Economy of ISIS. Atlantic Council. Accessed on November 3, 2019. Retrieved from https://www.atlanticcouncil.org/blogs/syriasource/raqqa-and-theoil-economy-of-isis/.

Madinger, J. (2012). Money Laundering: A Guide for Criminal Investigators. (3rd Edition). New York, United States of America: CRC Press Taylor and Francis Group, LLC.

Money Laundering in the EU; Methods and Stages of Money Laundering. Accessed on May 29, 2019. https://people.exeter.ac.uk/watupman/undergrad/ron/methods\%20and\%20stages.htm.

Oakes, C. J. (August 06, 2018). From Brooklyn to Palm Island: The Life of Alphonse Gabriel Capone. Accessed on November 5, 2019. Retrieved from https://brewminate.com/from-brooklyn-to-palmisland-the-life-of-alphonse-gabriel-capone/.

Peters, G. (2009). How Opium Profits the Taliban. United States Institute of Peace.

Rand Corporation. (n.d). The Cost of Terrorism in Europe. Accessed on June 30, 2019. Retrieved from https://www.rand.org/randeurope/research/projects/the-cost-of-terrorism-in-europe.html.

Raza, M. S., Fayyaz, M. and Ijaz, H. (2017). The Hawala System in Pakistan: A Catalyst for Money Laundering \& Terrorist Financing. Forensic Research \& Criminology International Journal. 5(4), 1-3. Accessed on November 10, 2019. Retrieved from https://medcraveonline.com/FRCIJ/FRCIJ-0500167.pdf.

Security Council Counter-terrorism Committee. (2001). United Nations Security Council resolution 1373. Accessed on April 05, 2020. Retrieved from https://www.un.org/sc/ctc/resources/databases/recommended-international-practices-codes-andstandards/united-nations-security-council-resolution-1373-2001/.

Thony, J. F. (2000). Money Laundering and Terrorism Financing: An Overview. International Monetary Fund (IMF).

United Nations Office on Drugs and Crime. (n.d). Money-Laundering and Globalization. Accessed on April 05, 2020. Retrieved from https://www.unodc.org/unodc/en/moneylaundering/globalization.html. 